\title{
Specificity and Juror Agreement in Civil Cases
}

\author{
Elizabeth A. Larsen $\dagger$
}

Imagine a product liability case in which the plaintiff has advanced evidence supporting two kinds of product defects: a manufacturing defect and a design defect. Six jurors believe a manufacturing defect has been proven by a preponderance of the evidence, but do not believe the design defect has been proven. The other six jurors believe that only the design defect has been sufficiently proven. If each juror were to vote solely on the existence of any product defect, the jury would return a unanimous verdict for the plaintiff.

Given a general verdict format, jurors probably will return a verdict for the plaintiff, unless they question whether their disagreement on the specifics invalidates that verdict. Given a specific verdict format asking separately about the design and manufacturing defects, the jurors will probably return a verdict for the defendant, unless, given that they all agree that the plaintiff should recover, they collude to show some agreement where none existed. Thus, whether a specific or general verdict form is submitted probably makes a difference in the verdict rendered. Even more troubling is the fact that the basic question arising from this situation has not been addressed by the presiding judge: Must the jurors specifically agree on which product defect existed?

Although this scenario seems likely to occur in product liability cases, the question of specificity in a jury's agreement is not limited to such cases. The problem can potentially arise in any case in which the plaintiff alleges multiple sets of facts that would allow her to recover from the defendant. ${ }^{1}$ For example, a plaintiff could allege that the defendant committed various negligent acts, where proof of any one of the acts alleged would allow her to recover. ${ }^{2}$ This Comment focuses on

\footnotetext{
$\dagger$ A.B. 1998, Princeton University; J.D. Candidate 2002, The University of Chicago.

1 Nor does this problem arise only when the plaintiff asserts multiple facts supporting some aspect of her case. The defendant may also offer multiple facts supporting a certain defense. One simple example is that a defendant trying to prove contributory negligence may assert various sets of facts showing negligence by the plaintiff.

2 The problem is most prevalent in tort cases, and consequently this Comment will focus on that area. However, one can imagine other areas of the law where the problem could arise: for example, those contesting a will might seek to establish lack of testamentary capacity through different sets of facts. See, for example, Ipsen $v$ Ruess, 241 Iowa 730, 41 NW2d 658, 664 (1950) (holding that separate interrogatories alleging that the "deceased did not have mental capacity (1), sufficient to know the extent of his property, (2), sufficient to know and comprehend in a general way the natural objects of his bounty, and (3), sufficient to know the distribution of his
} 
the problem of juror specificity in tort cases in which the plaintiff alleges multiple sets of facts to prove a single element of a cause of action such as negligence, product defect, or fraud.

This Comment begins with a discussion of the jury in Part I, in particular focusing on Supreme Court decisions on the jury, special verdicts and instructions, and models of juror decisionmaking and jury deliberation. Part II considers case law dealing with juror specificity in the civil context. It then describes how the Supreme Court has addressed the issue in the criminal context. Part III proposes a solution-that greater specificity should ordinarily be preferred. First, it describes the problems with the current approaches. In reaching the solution, the Comment draws analogies to the problem of specificity in the criminal law context. Due process and fairness concerns, as well as the purpose and strengths of the civil jury, support specificity. However, a significant exception exists in that specificity should not be required when a plaintiff is trying to prove her case using the res ipsa loquitur doctrine.

This Comment does not suggest that specificity is constitutionally mandated. Rather, it argues that judges, having great discretion in choosing jury instructions, should require specificity because it is a better policy than either failing to instruct the jury on the issue or instructing the jury that no agreement on specifics is required. Requiring specificity will improve deliberation and help the jury fulfill its factfinding mission.

\section{THE JURY}

This Part explores the nature of the jury by examining Supreme Court decisions on the jury, as well as scholarship and studies on juries. Particular attention is paid to jury instructions, different types of jury verdicts, juror decisionmaking, and jury deliberations.

\section{A. The Nature and Purpose of the Jury}

A good place to start is a discussion of Supreme Court cases that give some idea about what a jury must and should be. The Supreme Court has issued rulings dealing with the constitutional requirements for jury size and decision rules. The Court has also discussed what the purpose of the civil jury should be. 


\section{Jury size and decision rules.}

Prior to the 1970s, civil and criminal juries in the United States generally consisted of twelve members and returned unanimous verdicts. ${ }^{3}$ However, the Supreme Court later decided that in many situations juries could consist of fewer than twelve members and reach less than unanimous verdicts. ${ }^{4}$ Federal criminal juries must still consist of twelve members and decide unanimously. Federal civil juries may consist of six members, though they are still required to decide unanimously. ${ }^{6}$ State courts may have smaller juries and less stringent decisional rules even in the criminal setting, since the Fourteenth Amendment does not extend such incidents of the jury to the states. Although few states have adopted nonunanimous verdicts in criminal cases, many states have adopted some sort of supermajority requirement for juries in civil trials."

Some scholars suggest that jury theory supports a view of the jury as a collection of individuals rather than a coherent group. ${ }^{10}$ Hayden $\mathrm{J}$.

3 See Valerie P. Hans and Neil Vidmar, Judging the Jury 165-76 (Plenum 1986) (describing Supreme Court decisions on jury size and decision rules).

4 See id at 166, 168, 173. See also Johnson v Louisiana, 406 US 356, 363 (1972) (holding that a verdict rendered by nine out of twelve jurors in a state criminal trial was not a violation of due process); Williams v Florida, 399 US 78, 86 (1970) (holding that a twelve-person jury is not a necessary ingredient of trial by jury and that a jury of six persons was constitutional in a state criminal trial).

$5 \quad$ FRCrP 23(b) (size of jury); FRCrP 31(a) (unanimity requirement).

6 Colgrove v Battin, 413 US 149, 160 (1973); American Publishing Co v Fisher, 166 US 464, 467-68 (1897) (requiring unanimity for federal civil jury trials under the Seventh Amendment). See also Johnson, 406 US at 369-70 (Powell concurring) (noting that unanimity is an indispensable feature of the federal jury trial). In 1991, the Federal Rules of Civil Procedure were amended to reflect this change, given that many federal district courts were then seating juries of six as a matter of course. FRCP 48, Advisory Committee's Note to the 1991 Amendments. Verdicts are generally required to be unanimous, though the parties may stipulate to some sort of majority verdict. Id. Parties may also stipulate to fewer than six jurors, see FRCP 48, although this is discouraged, because the Court disallowed criminal juries of fewer than six in Ballew v Georgia, 435 US 223, 239 (1978).

7 See, for example, Johnson, 406 US at 363; Williams, 399 US at 86.

8 Louisiana and Oregon, whose nonunanimous verdicts were originally challenged and found constitutional in the 1970 s, are still the only states to allow nonunanimous criminal verdicts. See Kate Stith-Cabranes, The Criminal Jury in Our Time, 3 Va J Soc Pol \& L 133, 141-42 (1995) (noting that other states have considered making the change).

9 Saul Levmore, Conjunction and Aggregation, 99 Mich L Rev 723, 740 n 33 (2001) ("Roughly speaking, more than a third of the states require unanimity in civil cases.").

10 See Hayden J. Trubitt, Patchwork Verdicts, Different-Jurors Verdicts, and American Jury Theory: Whether Verdicts Are Invalidated by Juror Disagreement on Issues, 36 Okla L Rev 473, 476-77 (1983) (specifically discussing Johnson as supporting the ideal of individualism). Trubitt adopts the name "patchwork verdict" for verdicts where the jurors agree on the general verdict but disagree on the particulars behind the verdict. Id at $474 \mathrm{n} 1$ (noting that the term was coined in Comment, Right to Jury Unanimity on Material Fact Issues: United States v. Gipson, 91 Harv L Rev 499 (1977)). Justice Ginsburg has also argued that the nature of the jury as a group of individuals counsels that agreement on specifics should not be required; however, her article was written before the Supreme Court rendered its decisions on jury size and decision rules. See 
Trubitt argued that agreement on specifics should not be required because a jury is a collection of individuals. Trubitt reasoned that by allowing nonunanimous verdicts, the Supreme Court demonstrated a commitment to individualism, since "if the jury is thought to be a single holistic entity, the dissent of [any] jurors" should prevent the jury from rendering a verdict." Therefore, Trubitt proposed that civil "[p]atchwork verdicts are, in general, valid and proper." ${ }^{\text {"12 }} \mathrm{He}$ suggested an exception to this rule "where the 'patched' grounds are not part of a sole transaction, do not have a common focus of injury, or do not call for exactly the same remedy." ${ }^{, 13}$ Although Trubitt drew from Court decisions suggesting that the jury is a collection of individuals, the Court has equally emphasized the jury as a deliberative body. ${ }^{14}$

\section{Jury as factfinder.}

The most important mission of the jury, at least in civil cases, is to determine what facts have been proven. Historically, juries have it within their power to judge both law and fact. ${ }^{15}$ With a general verdict, a jury is instructed on the law and is presumed to follow these instructions. ${ }^{16}$ Many issues cannot easily be split into law and fact, and the jury ends up deciding mixed issues, such as negligence."

In the criminal context, juries continue to decide facts and apply law to these facts, ${ }^{18}$ but some of the civil jury's lawmaking power has been taken over by judges, particularly through devices such as the special verdict. ${ }^{19}$ The civil jury continues to be generally respected as a

Ruth B. Ginsburg, Special Findings and Jury Unanimity in the Federal Courts, 65 Colum L Rev 256, 268 (1965) (rejecting the "particular fact definition" because "rigidly and unrealistically, [it] equates the collective judgment of twelve with the individual judgment of a single trier").

11 Trubitt, 36 Okla L Rev at 476 (cited in note 10) ("The theme of individualism focuses on the means by which verdicts are rendered. Ideally, a verdict is a concurrence of the views of all jurors, each view representing an individual and independent assessment of the evidence.").

12 Id at 511.

13 Id.

14 For more on the importance of the jury as a deliberative body, see Part I.C.2.

15 See, for example, Georgia v Brailsford, 3 US (3 Dall) 1, 4 (1794) (charging the jury: "[A]s, on the one hand, it is presumed, that juries are the best judges of facts; it is, on the other hand, presumable, that the court are [sic] the best judges of law. But still, both objects are lawfully within your power of decision.").

16 See, for example, Richardson $v$ Marsh, 481 US 200, 211 (1987) (noting the pragmatic rule that juries are presumed to follow their instructions).

17 See, for example, Isham v Post, 141 NY 100, 35 NE 1084, 1085 (1894) ("Negligence is usually a mixed question of law and fact."). See also Dan B. Dobbs, The Law of Torts 258 (West 2000) ("Overall, juries are a highly significant force in deciding negligence and are subject to fewer restrictions than in some other kinds of tort cases.").

18 United States $v$ Gaudin, 515 US 506, 511-15 (1995) (concluding that the jury's responsibility is not merely to determine facts but to apply law to those facts and make the ultimate conclusions as to guilt or innocence).

19 See Part I.B.2 for a discussion of special verdicts and general verdicts accompanied by interrogatories. 
factfinding institution. ${ }^{20}$ The criminal jury has an additional function beyond factfinding: to stand between the defendant and the government. ${ }^{21}$ However, the purpose of the civil jury is "to assure a fair and equitable resolution of factual issues." ${ }^{22}$ Since civil juries serve no protective function, their role as factfinding bodies is comparatively more important.

\section{B. Instructing and Controlling the Jury}

This Part discusses the literature on jury instructions, noting that greater clarity in jury instructions is generally desirable. It also considers different verdict structures, particularly emphasizing the special verdict, which attempts to remove some lawmaking ability from the jury.

\section{Jury instructions.}

The literature reveals considerable doubts about how closely juries follow jury instructions. Doubts about the efficacy of jury instructions come from both the nature of jury instructions and beliefs about the competence of the jury. ${ }^{23}$

Jury instructions have faced much criticism for their lack of clarity. Most states encourage judges to use "pattern," "standard," or "uniform" jury instructions. ${ }^{24}$ Such pattern instructions are often written with more attention to precise legal accuracy than to clarity of instruction. ${ }^{25}$ Some scholars have suggested that jury instructions could

20 Hans and Vidmar, Judging the Jury at 245 (cited in note 3) (concluding that juries are generally competent factfinders). However, some commentators and courts have suggested that the jury be abolished in complex civil cases. See generally Richard Lempert, Civil Juries and Complex Cases: Taking Stock after Twelve Years, in Robert E. Litan, ed, Verdict: Assessing the Civil Jury System 181 (Brookings 1993) (discussing the debate over whether a complexity exception should be read into the Seventh Amendment).

21 Duncan v Louisiana, 391 US 145, 156 (1968):

Providing an accused with the right to be tried by a jury of his peers gave him an inestimable safeguard against the corrupt or overzealous prosecutor and against the compliant, biased, or eccentric judge. If the defendant preferred the common-sense judgment of a jury to the more tutored but perhaps less sympathetic reaction of the single judge, he was to have it.

22 Colgrove v Battin, 413 US 149, 157 (1973).

23 The question of the jury's general competence is beyond the scope of this Comment, but for a general discussion of the debate on jury competence, see Hans and Vidmar, Judging the Jury at 113-29 (cited in note 3 ) (concluding that juries are generally competent).

24 See Amiram Elwork, James J. Alfini, and Bruce D. Sales, Toward Understandable Jury Instructions, in Lawrence S. Wrightsman, Saul M. Kassin, and Cynthia E. Willis, eds, In the Jury Box: Controversies in the Courtroom 161, 162 (Sage 1987).

25 See Jonathan D. Casper, Restructuring the Traditional Civil Jury: The Effects of Changes in Composition and Procedures, in Robert E. Litan, ed, Verdict: Assessing the Civil Jury System 414, 444 (Brookings 1993) (describing pattern instructions as containing "highly complex circumlocutions, arcane language and concepts, and elaborate series of contingent judgments"). See also 
be rewritten to be more comprehensible. ${ }^{26}$ Others argue that confusing jury instructions are unavoidable because they reflect the complexity of the law; any attempt to clarify jury instructions will result in incorrect statements of the law. ${ }^{27}$

Pattern jury instructions for civil cases do not recognize the issue of specificity of juror agreement. Some of them suggest that agreement on specificity may not be required, since they instruct the jurors that they need only agree on elements. ${ }^{28}$ Others, by referring more specifically to the facts, suggest that agreement may be required. ${ }^{29}$ Nonetheless, none of the instructions explicitly addresses the issue of specificity of juror agreement, so jurors are left largely to their own devices.

\section{Types of verdicts.}

One development that has greatly changed the jury system in civil cases over the last forty years is the growing acceptance and use of the special verdict. ${ }^{30}$ Special verdicts come in many different forms,

Elwork, Alfini, and Sales, Toward Understandable Jury Instructions at 162 (cited in note 24) (noting that although pattern instructions may conserve lawyers' and judges' time and reduce the number of reversals based on legally erroneous instructions, they do not seem to increase jurors' comprehension); Saul M. Kassin and Lawrence S. Wrightsman, The American Jury on Trial: Psychological Perspectives 149 (Hemisphere 1988) (arguing that problems with jury competence arise not from "jury comprehension, but the comprehensibility of judges' instructions"); Hans and Vidmar, Judging the Jury at 120-24 (cited in note 3) (describing how the clarity of jury instructions can be enhanced without sacrificing legal accuracy).

26 See Elwork, Alfini, and Sales, Toward Understandable Jury Instructions at 176 (cited in note 24) (summarizing a mock jury study that suggested that juror comprehension of judicial instructions could be increased significantly by using simpler instructions).

27 See, for example, Kassin and Wrightsman, The American Jury on Trial at 151 (cited in note 25), quoting $B A J I$ (4th ed 1954) (noting that the authors of some jury instructions claim that "the one thing an instruction must do above all else is correctly state the law. This is true regardless of who is capable of understanding it.").

28 See, for example, Michigan Supreme Court Committee on Standard Jury Instructions, 1 Michigan Standard Jury Instructions $\$ 16.02$ (Inst for Continuing Legal Educ 2d ed 1998) ("The plaintiff has the burden of proof on each of the following propositions: a. that the plaintiff was injured[;] $b$. that the defendant was negligent in one or more of the ways claimed by the plaintiff, as stated to you in these instructions[;] c. that the negligence of the defendant was a proximate cause of the injuries to the plaintiff."); Oregon State Bar Committee on Uniform Civil Jury Instructions, Oregon Jury Instructions for Civil Cases $\$ 20.01$ (Or State Bar 1993) ("To recover, the plaintiff must prove by a preponderance of the evidence that the defendant was negligent in at least one respect charged in the plaintiff's complaint which was a cause of damage to the plaintiff.").

29 See, for example, Walter L. Murphy and Daniel C. Pope, eds, New Hampshire Civil Jury Instructions $\$ 1.1$ (Matthew Bender 3d ed 2000) ("This is a civil action in which the plaintiff [] has sued the defendant [ ] to recover money damages for [] sustained on [ ] at [ ]. (Describe briefly the plaintiff's claim). The plaintiff claims: (State essential elements of the claim, making reference to time, place, and circumstances).").

30 The Federal Rules of Civil Procedure authorize the use of special verdicts and interrogatories. FRCP 49. Most state procedures also allow some sort of special verdict or general verdict with interrogatories. Geoffrey C. Hazard, Jr., Colin C. Tait, and William A. Fletcher, Pleading and 
and Federal Rule of Civil Procedure 49 gives considerable discretion to the trial judge in deciding whether to use a general verdict, a special verdict, or a general verdict with interrogatories. ${ }^{31}$ The special verdict is to be "in the form of a special written finding upon each issue of fact. ${ }^{32}$ The judge then applies the law to the jury's findings and enters the appropriate verdict.

The judge may also submit a general verdict with written interrogatories "upon one or more issues of fact the decision of which is necessary to a verdict. ${ }^{\text {34 }}$ If the general verdict and the interrogatories are harmonious, the judge enters the appropriate judgment. ${ }^{35}$ However, if the general verdict and the interrogatories conflict, the judge may decide to enter a judgment in accordance with the interrogatories. ${ }^{36} \mathrm{He}$ may also send the jury back for further deliberations on its answers or verdict or order a new trial.

The special verdict, especially one that asks the jury only to determine issues of fact, essentially takes away any law-determining ability that might be within the jury's power. ${ }^{38}$ Special verdicts originally received both praise and criticism because they were used to keep the jury in the dark about the significance of their answers. ${ }^{39}$ However, juries today are routinely informed on how their answers to a special verdict will affect the verdict."

Procedure: State and Federal 1230 (Foundation 8th ed 1999) ("[M]ost state procedures have permissible variations [of special verdicts], which include a general verdict accompanied by special findings or by answers to special interrogatories.").

31 See Robert M. Dudnik, Comment, Special Verdicts: Rule 49 of the Federal Rules of Civil Procedure, 74 Yale L J 483, 483 (1965) (describing the discretionary choice left to the judges and criticizing FRCP 49 because it "did not provide any standards or guides to aid in the exercise of this discretion").

32 FRCP 49(a).

33 Id.

34 FRCP 49(b).

35 Id.

36 Id.

37 Id.

38 G. Thomas Munsterman, Paula L. Hannaford, and G. Marc Whitehead, eds, Jury Trial Innovations 189 (National Center for State Courts 1997) ("Special verdicts constrain the jury's prerogatives and its ability to dispense a 'people's justice."').

39 Martin A. Kotler, Reappraising the Jury's Role as Finder of Fact, $20 \mathrm{Ga}$ L Rev 123, 135 \& n 34 (1985) (indicating that traditionally juries were not informed of the legal effect of their answers in special findings because this would defeat the use of the special verdict "'to secure fair and impartial answers to such questions"), quoting Coats v Town of Stanton, 90 Wis 130, 62 NW 619, 621 (1895). See also Dudnik, Comment, 74 Yale L J at 493 (cited in note 31) (noting the traditional premise that the average juror will have no common knowledge of the relationship between the ultimate facts he is called upon to find and the result that would follow, and rejecting this premise as unsound).

40 Kotler, $20 \mathrm{Ga} \mathrm{L} \mathrm{Rev}$ at 124 (cited in note 39) (noting that only a small minority of jurisdictions now follow the traditional rule of nondisclosure). 
Long before the adoption of Rule 49, the special verdict was seen as a way of controlling the jury. ${ }^{41}$ Even more than jury instructions, the special verdict requires careful application, because it greatly decreases the jury's flexibility in making its decision and leaves the jury only factfinding powers.

The use of special verdicts and interrogatories raises the question of how specific such questions should be. The Rules instruct that special verdicts are submitted "upon each issue of fact." Interrogatories may be submitted "upon one or more issues of fact the decision of which is necessary to a verdict." ${ }^{\prime 4}$ However, this rule still gives little guidance as to how specific such special verdicts should be.

\section{Decisionmaking and Deliberation}

This Part discusses how jurors and juries render verdicts. First, it considers how individual jurors evaluate evidence and make decisions on guilt or liability. Second, it discusses what happens when jurors deliberate collectively in order to reach a decision that represents the findings of the jury.

\section{Models of individual juror decisionmaking.}

This Part describes two models of individual juror decisionmaking: the story model and the meter-reader model. Some scholars suggest that a juror's approach to evidence resembles an attempt to construct a plausible story rather than an element-by-element approach. The model suggests that jurors impose a narrative story organization on the information they receive at trial. ${ }^{47}$ Moreover, litigators may

41 See, for example, Dudnik, Comment, 74 Yale L J at 489-91 (cited in note 31) (describing how early proponents of the special verdict argued that the "merger of fact and law in the general verdict [ ] made it impossible for courts to exercise control over irresponsible jurors because there was no way to tell what facts had been found nor what law had been applied").

42 See id at 490 (stating that supporters "claimed that the jury would be confined to its proper role as an impartial, rational finder of fact").

43 FRCP 49(a).

44 FRCP 49(b).

45 Munsterman, Hannaford, and Whitehead, eds, Jury Trial Innovations at 187 (cited in note 38) (noting that the appropriate specificity level of special verdicts is an open question). See also Elizabeth C. Wiggins and Steven J. Breckler, Special Verdicts as Guides to Jury Decision Making, 14 L \& Psych Rev 1, 3 n 7 (1990) (noting that because of the latitude given the trial judge, special verdicts may consist of fairly precise factual questions or mixed questions of law and fact).

46 See Nancy Pennington and Reid Hastie, The Story Model for Juror Decision Making, in Reid Hastie, ed, Inside the Juror: The Psychology of Juror Decision Making 192, 192-203 (Cambridge 1993) (suggesting that jurors evaluate evidence to construct a story and then match the story to the best-fitting verdict category). See also Richard Lempert, Telling Tales in Court: Trial Procedure and the Story Model, 13 Cardozo L Rev 559, 559 (1991) (evaluating the role that stories play in the trial process).

47 Pennington and Hastie, The Story Model at 194 (cited in note 46). 
contribute to the story effect, since they may present the case as a story, instinctively sensing that is how jurors best process information.

Although all jurors hear the same information, a central claim of the story model is that different jurors will construct different stories, and each juror's story will determine the verdict that the juror reaches individually. ${ }^{49}$ The different stories the jurors construct do not depend so much on the information they receive at trial, which is roughly similar for all jurors, but rather on the differences in world knowledge among the jurors. ${ }^{{ }^{0}}$ These differences in world knowledge lead jurors to make different inferences from the evidence. ${ }^{\text {st }}$

The story model contrasts with another model of juror decisionmaking, the juror as "meter reader." ${ }^{\text {s2 }}$ Meter-reader models assume that jurors use a quantitative approach to the evidence. ${ }^{53}$ Such models focus on a process called "anchoring and adjustment," where "the juror anchors on some initial value and then adjusts this value in light of each new piece of evidence." ${ }^{54}$ Although it is uncertain which of these models is a more accurate description of the juror's decisionmaking, evidence seems to suggest that there is some truth in each.

\section{The jury as deliberative body.}

Although models of individual juror decisionmaking can shed some light on jury behavior, the jury is ultimately a deliberative decisionmaking body. In its cases on the constitutional requirements for the size of the jury, the Supreme Court has noted, "What is required for a 'jury' is a number large enough to facilitate group deliberation combined with a likelihood of obtaining a representative cross section

48 See Lempert, 13 Cardozo L Rev at 562 (cited in note 46) (finding that juries tend to evaluate veracity on the basis of the coherency of the story offered at trial).

49 Pennington and Hastie, The Story Model at 196 (cited in note 46).

50 Id.

51 Id. For example, some jurors might think a confrontation with a bully might make the defendant frightened (leading toward a finding of self-defense), but other jurors might believe the confrontation would be a challenge to manly pride resulting in anger (leading away from a finding of self-defense). Id at 195-96.

52 See Lola Lopes, Two Conceptions of the Juror, in Reid Hastie, ed, Inside the Juror: The Psychology of Juror Decision Making 255 (Cambridge 1993). See also Robert MacCoun, Inside the Black Box: What Empirical Research Tells Us about Decisionmaking by Civil Juries, in Robert E. Litan, ed, Verdict:Assessing the Civil Jury System 137, 152 (Brookings 1993).

53 Lopes, Two Conceptions of the Juror at 255 (cited in note 52). Scholars have articulated many different subtheories about how jurors use quantitative methods in approaching decisionmaking. See Reid Hastie, Introduction, in Reid Hastie, ed, Inside the Juror: The Psychology of Juror Decision Making 3, 10-22 (Cambridge 1993) (describing models based on probability theory, "cognitive" algebra, and stochastic processes).

54 MacCoun, Inside the Black Box at 152 (cited in note 52).

55 Id at 153. 
of the community." ${ }^{, 56}$ The Court professes great faith in the ability of the jury to deliberate fairly and reasonably, even when a unanimous verdict is not required. ${ }^{57}$

The importance of deliberation is highlighted by studies suggesting that with as many as nine out of ten juries, the verdict reached matches the original verdict preferences of the jurors. ${ }^{58}$ Even if this percentage is correct, it still means that in one out of ten cases, deliberation may change a jury's verdict. Thus, fairness dictates that deliberation should be encouraged through whatever tools necessary. ${ }^{59}$ Deliberation is vital no matter which model of individual juror decisionmaking is accurate. If jurors act more as meter-readers, deliberation will force them to consider bits of evidence that they may have overlooked. If juror decisionmaking conforms to the story model, deliberation will ensure that jurors reach appropriately coherent stories that take into account all of the evidence presented at trial.

\section{CASE LAW ON SPECIFICITY REQUIREMENTS}

Although juries must face this issue relatively often, whenever plaintiffs or defendants plead multiple facts, courts have addressed the problem only rarely. This Part examines approaches in two different states, California and Kansas, that have faced the issue relatively recently. ${ }^{6}$ This Part also describes how the Supreme Court has decided the issue of specificity in the criminal context.

56 Colgrove v Battin, 413 US 149, 160 n 16 (1973).

57 Johnson v Louisiana, 406 US 356, 361 (1972):

We have no grounds for believing that majority jurors, aware of their responsibility and power over the liberty of the defendant, would simply refuse to listen to arguments presented to them in favor of acquittal, terminate discussion, and render a verdict.... A majority will cease discussion and outvote a minority only after reasoned discussion has ceased to have persuasive effect or to serve any other purpose.

Compare id at 388 (Douglas dissenting) ("[N]onunanimous juries need not debate and deliberate as fully as must unanimous juries. As soon as the requisite majority is attained, further consideration is not required either by Oregon or by Louisiana even though the dissident jurors might, if given the chance, be able to convince the majority.").

58 Phoebe C. Ellsworth, Some Steps between Attitudes and Verdicts, in Reid Hastie, ed, Inside the Juror: The Psychology of Juror Decision Making 42, 58 (Cambridge 1993) (acknowledging the nine out of ten figure, but arguing that three out of four may be the closer figure).

59 Id at 58-59 (noting that a convicted defendant would surely feel cheated if the jury returned a verdict after an initial vote without deliberation).

60 For a discussion of how requiring specificity will encourage deliberation, see text accompanying notes $147-52$.

61 There are several earlier examples where courts dealt with the problem of specificity of juror agreement, but this Comment does not focus on such cases, which have already been discussed in other commentaries. See, for example, Ginsburg, 65 Colum L Rev at 260-62 (cited in note 10); Patrick Woolley, Mass Tort Litigation and the Seventh Amendment Reexamination Clause, 83 Iowa L Rev 499, 529-30 nn 149-52 (1998). 


\section{A. California:The Primary Rights Theory}

A California appellate court first addressed the problem of what jurors must agree on in civil cases in Stoner $v$ Williams. ${ }^{62}$ Stoner brought a fraud action against an adoption agency and Williams, one of its employees, alleging that the defendants had committed fraudulent acts in convincing her to give up her baby for adoption. ${ }^{63}$ The plaintiff had the burden of proving the facts necessary to establish one or more of the seven fraudulent acts alleged. ${ }^{64}$ After one day of deliberation, the jury asked the court whether "a minimum of 9 jurors need to agree that the same allegation[] has been proven or could some agree that one has been proven and others a different one as long as 9 agree that at least one has been proven." ${ }^{65}$ The court responded that it was not necessary that nine jurors agree on a specific fraudulent act of the seven alleged, as long as each of the nine believed that any one of the fraudulent acts had been committed. ${ }^{66}$ The jury returned a verdict in favor of Stoner shortly thereafter. ${ }^{67}$ The adoption agency appealed the case and a California appellate court affirmed. ${ }^{63}$

Expressing surprise that it was unable to find any authority addressing the question of juror agreement in the civil context, the appellate court turned to the criminal context. ${ }^{69}$ Under California law:

[I]f only one criminal offense could exist as a result of the commission of various acts, the jury need not agree on which particular act (or legal theory) a criminal conviction is based, provided the jurors unanimously agree that all elements of the criminal offense are proved beyond a reasonable doubt. ${ }^{70}$

6246 Cal App 4th 986, 54 Cal Rptr 2d 243 (1996).

6354 Cal Rptr 2 d at 245-46.

64 Id at 246-47. The fraudulent acts alleged included misrepresentation of the full range of alternatives open to Stoner, concealment of the fact that the adoption agency was unlicensed, and assumption by the adoption agency and its employees of the role of Stoner's advocate in representing her interests. Id.

65 Id at 247. California law allows civil verdicts to be rendered by nine out of twelve jurors. Id at 254.

66 Id at 247. The trial court judge explained his reasoning with a comparison:

I analogize it to an automobile accident case where you might have somebody who is speeding, improperly making a turn and maybe had a few drinks. And when the jury is asked whether the defendant was negligent, they can have different decisions. One can decide he was negligent because he was speeding and one can decide he was negligent because of the turn issue. They don't have to agree on the same act. They have to agree that the act was negligent and that the negligence caused injury.

Id at 248.

67 Id at 247.

68 Id at 244.

69 Id at 248-49.

70 Id at 249. 
The court also noted that the vast majority of other state and federal courts agreed on this standard for criminal cases."

Although admitting that "comparing civil law with criminal law is sometimes like comparing apples with oranges," the court believed the comparison was useful here. ${ }^{n}$ Since the criminal law system generally places a higher burden on the prosecutor than the civil law places on the plaintiff, the court determined that the rules of jury agreement should not be more onerous for the civil plaintiff than for the criminal prosecutor. ${ }^{\text {Th }}$ Criminal juries must agree on the same ultimate criminal offense, but not on the theory behind the offense (for example, committing the offense or aiding and abetting) or on the acts performed in committing the offense. ${ }^{74}$ The Stoner court likened a single, discrete criminal offense to a single cause of action in a civil case. ${ }^{75}$ Therefore, civil juries must agree that each of the elements of a single cause of action has been proven, but do not need to agree on the specific way in which each element is proven. The court noted that especially if multiple causes of actions were charged in the same civil case, it would be important to instruct the jurors that they would have to agree on the same cause of action and not simply on the end result of liability. ${ }^{76}$

The court then discussed the appropriate way in which to define a single cause of action. It determined that the primary rights theory was the appropriate way to ascertain whether multiple causes of action existed." Under the primary rights theory, the invasion of a single primary right leads to a single cause of action. ${ }^{78}$ Thus, the court must look to the harm allegedly suffered by the plaintiff rather than the legal theory asserted.' If the plaintiff has suffered one injury, then only one cause of action arises.

Applying the primary rights theory to the Stoner case, the court held that the injury was the "personal injury [plaintiff] suffered as the result of the loss of her child." ${ }^{81}$ The seven fraudulent acts alleged caused that same injury and were violations of the same primary right. $^{82}$ Therefore, the court appropriately instructed the jurors that they need not agree on the specific fraudulent act performed.

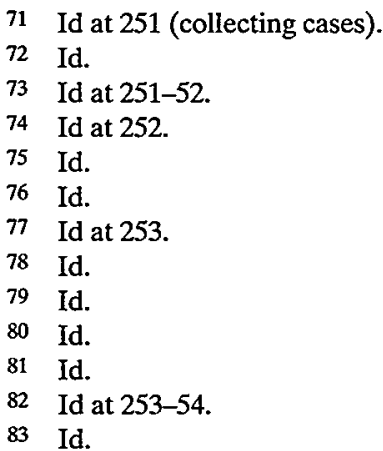


In Valentine $v$ Baxter Healthcare Corp ${ }^{84}$ another California appellate court revisited the issue of specific agreement among jurors and applied the reasoning in Stoner to a product liability case. The plaintiff in Valentine sued a breast implant manufacturer on behalf of his deceased wife. After one trial in which the jury found for the defendant on some issues and hung on others, there was a second trial. ${ }^{\text {sf }}$ At that trial, the court gave the jury specific instructions on five negligence theories: design, testing, inspection, warning, and manufacture. ${ }^{.7}$ Applying the primary rights theory, the appellate court noted that the single primary right injured by the breast implant manufacturer was the right not to be supplied with a negligently made implant. ${ }^{8 s}$ Though affirming the reasoning of Stoner, the court held that the submission of special verdicts did not harm the plaintiff here because nine jurors still did not concur on causation.

\section{B. Kansas: An Intuitive Approach}

Although the California courts have given the most comprehensive recent attention to the question of specificity of jury agreement in civil trials, the Kansas Supreme Court has also addressed the issue, deciding that allowing disagreement on specifics was more intuitively attractive.

In Cleveland $v$ Wong, ${ }^{\infty}$ a medical malpractice case, the trial judge instructed the jury on six different claims of negligence, including failure to prescribe an appropriate antibiotic, performing surgery without adequate medical justification, and various negligent acts done during the course of surgery. ${ }^{91}$ The jurors sent a question to the judge asking whether they needed to agree on a specific negligent act or could merely agree on the existence of negligence. ${ }^{2 /}$ The judge instructed the jurors that they need agree only on the existence of negligence, not on a specific act. $^{93}$

8468 Cal App 4th 1467, 81 Cal Rptr 2d 252 (1999).

$8581 \mathrm{Cal} \mathrm{Rptr} 2 \mathrm{~d}$ at $254,255 \mathrm{n} 1$.

86 Id at 254 (noting that the first jury found for the defense on strict liability and fraud but hung on the causation element of the negligence count).

87 Id at $261 \& \mathbf{n} 11$.

88 Id at 265 . The court also noted that negligent failure to warn might involve a separate primary right than the other negligence claims; however, that was irrelevant since the negligent failure to warn should not have been argued in the second trial at all. Id at $265-66 \mathrm{n} 15$.

89 Id at $265-66$.

$90237 \mathrm{Kan} 410,701 \mathrm{P} 2 \mathrm{~d} 1301$ (1985).

91 Cleveland, $701 \mathrm{P} 2 \mathrm{~d}$ at 1307.

92 See id.

93 See id. 
The Kansas Supreme Court affirmed. Unlike the California courts, the Kansas court offered no theory, just common sense, remarking:

In a negligence case involving automobiles, if half of the jurors determine that the defendant failed to keep a proper lookout, and that such failure caused the collision and plaintiff's resulting injuries and damages, and the other half of the jurors determine that the defendant ran a stop sign, thus causing the collision and the injuries complained of, and assuming that there is evidence to support both, should the plaintiff be denied recovery?

Thus, both Kansas and California reached the same determination that specificity should be required, although they used very different reasoning to reach their conclusions.

\section{Schad v Arizona: A Supreme Court Decision on Specificity in the} Criminal Law Context

In the criminal law context, there have been more cases discussing what juries must decide with specificity, including Supreme Court decisions. Analogies to the criminal law can be useful in this area, since basic values of the jury system are common to both the criminal and civil law situations.

One important case in this area is Schad v Arizona. Schad was convicted of first-degree murder under an Arizona statute that defines first-degree murder as either premeditated murder or felony murder. ${ }^{96}$ At the defendant's trial, the prosecutor argued both theories. ${ }^{\text {s7 }}$ The court instructed the jury that first-degree murder was the result of premeditation and that murder committed during an attempted robbery is also first-degree murder. ${ }^{98}$ The jury was then instructed that it must unanimously agree "whether the verdict is guilty or not guilty.", The court gave the jury three choices: guilty of first-degree murder, guilty of second-degree murder, and not guilty. ${ }^{100}$ The Arizona Supreme Court affirmed the conviction, and the U.S. Supreme Court granted certiorari to determine "whether it was constitutionally acceptable to permit the jurors to reach one verdict based on any combination of the alternative findings."

\footnotetext{
94 Id at 1308.

95501 US 624 (1991).

96 See id at 628.

97 Id at 629.

98 Id.

99 Id.

100 Id.

101 Id at 629-30.
} 
The Supreme Court noted that it was a longstanding rule that "an indictment need not specify which overt act, among several named, was the means by which a crime was committed. ${ }^{102}$ Furthermore, this rule is embodied in the Federal Rules of Criminal Procedure, which provide: "It may be alleged in a single count that the means by which the defendant committed the offense are unknown or that the defendant committed it by one or more specified means." ${ }^{, 103}$

The Court emphasized that a state has wide latitude in defining alternative means by which a crime may be proven. ${ }^{104}$ However, despite such deference, there are limits on the state's power in defining crimes. ${ }^{105}$ The problem is to describe "the point at which differences between means become so important that they may not reasonably be viewed as alternatives to a common end, but must be treated as differentiating what the Constitution requires to be treated as separate offenses." "106 The Court had never defined exactly how to determine that point. Much of the prior case law on how to distinguish between legitimate alternative means and differentiated offenses came from a Fifth Circuit case, United States v Gipson. ${ }^{107}$

In Gipson, the defendant was charged with violating 18 USC $\S 2313$, which prohibited knowingly "receiving, concealing, storing, bartering, selling or disposing" of any stolen vehicle moving in interstate commerce. ${ }^{108}$ The defendant was convicted after the trial judge instructed the jurors that they need not agree on which of the enumerated acts the defendant had committed. The Fifth Circuit reversed the conviction, reasoning that the enumerated acts actually consisted of two distinct conceptual groupings, "housing" and "marketing." According to the Gipson court, when acts are within the same conceptual grouping, the jurors need not agree on which specific act was performed. ${ }^{110} \mathrm{~A}$ number of lower courts adopted the conceptual grouping test."

102 Id at 631. For example, the Court had sustained a murder conviction in which the Government advanced theories of both shooting and drowning. Andersen $v$ United States, 170 US 481, 492-94 (1898). The Court has also approved convictions in which the charge failed to specify which of three defendants did the actual killing and which were guilty on an accomplice theory. See Borum v United States, 284 US 596, 596-97 (1932).

103 Schad, 501 US at 631 (internal quotation marks omitted), quoting FRCIP 7(c)(1).

104 Schad, 501 US at 638 ("Respect for [ ] legislative competence counsels restraint against judicial second-guessing.").

105 Id at 639 (noting that although the state legislature's definition is usually dispositive, "'there are obviously constitutional limits beyond which the States may not go"'), quoting Patterson $v$ New York, 432 US 197, 210 (1977).

106 Schad, 501 US at 633.

107553 F2d 453 (5th Cir 1977).

108 Id at 458.

109 Id.

110 See id.

111 See Schad, 501 US at 634-35 (collecting cases). 
The Schad Court rejected the Gipson conceptual grouping approach as "too indeterminate to provide concrete guidance to courts faced with verdict specificity questions." ceptual groupings may be identified at various levels of generality, and we have no a priori standard to determine what level of generality is appropriate."113

After rejecting the dissent's policy of requiring maximum verdict specificity, ${ }^{114}$ the Court abandoned the attempt to come up with a conclusive test, convinced of "the impracticability of trying to derive any single test for the level of definitional and verdict specificity permitted by the Constitution." specificity is a distillate of the concept of due process with its demands for fundamental fairness and for the rationality that is an essential component of that fairness." ${ }^{116}$ In making this due process analysis, courts should exercise judicial restraint, since definitions of crimes "represent value choices more appropriately made in the first instance by a legislature than by a court."

Considering the alternative theories of premeditated first-degree murder and felony murder, the Court affirmed the conviction. In making its decision, the Court noted that " $[t]$ he use here of due process as a measurement of the sense of appropriate specificity assumes the importance of history and widely shared practice as concrete indicators of what fundamental fairness and rationality require."118 The case for not requiring specificity was particularly strong here, where premeditated and felony murder had long been alternative theories for firstdegree murder. The Court also discussed the potential moral equivalence of the two acts, a premeditated murder and a shooting during an armed robbery. ${ }^{119}$ Although affirming the conviction, the Court added, "We do not, of course, suggest that jury instructions requiring increased verdict specificity are not desirable .... We hold only that the Constitution did not command such a practice on the facts of this case." ${ }^{120}$

In his concurrence, Justice Scalia criticized the Court's opinion. He argued that only the endorsement of history supported the Court's

112 Id at 635.

113 Id.

114 Id at 636-37 (arguing that the dissent's test is insufficiently respectful of state legislature's crime definitions, which the Court is required to respect).

115 Id at 637.

116 Id (citation omitted).

117 Id at 638 .

118 Id at 640 .

119 Id at 643-44.

120 Id at 645 . 
contention that juror agreement was not needed. ${ }^{121}$ Discussing the rule that jurors need not agree upon the mode of commission, he also noted that this rule was "not only constitutional ... [but] probably indispensable in a system that requires a unanimous jury verdict to convict." ${ }^{122} \mathrm{He}$ was extremely critical of the Court's moral equivalence arguments:

Perhaps moral equivalence is a necessary condition for allowing such a verdict to stand, but surely the plurality does not pretend that it is sufficient. (We would not permit, for example, an indictment charging that the defendant assaulted either $\mathrm{X}$ on Tuesday or $\mathrm{Y}$ on Wednesday, despite the "moral equivalence" of those two acts. $)^{123}$

Four justices dissented in Schad. Writing for the dissenters, Justice White criticized a conviction where "it is entirely possible that half of the jury believed the defendant was guilty of premeditated murder and not guilty of felony murder/robbery, while half believed exactly the reverse." ${ }^{124}$ White, while agreeing that a state is surely entitled to deference in defining the elements of the offense, argued that the state had then defined different elements for premeditated murder and felony murder and must be held to its definition.

\section{PROBLEMS WITH CURRENT APPROACHES AND A SOLUTION: REQUIRING GREATER SPECIFICITY}

This Part describes the problems with the current approaches used by the California and Kansas courts. It then proposes that courts should generally instruct juries that they must agree on specifics. Due process and fairness concerns gleaned from the criminal law context favor specificity. Moreover, requiring specificity will foster better deliberation. In implementing this policy, judges should make an exception in cases in which res ipsa loquitur applies. In all other cases, since the Federal Rules of Civil Procedure (and similar state rules) ${ }^{126}$ give

121 Id at 651 (Scalia concurring) ("If I did not believe that" this practice conformed with due process, since it is as old as the common law and still in existence in the majority of states, "I might well be with the dissenters in this case.").

122 Id at 650 .

123 Id at 651 .

124 Id at 655 (White dissenting).

125 Id at 657-58. White noted that even the prosecutor in his closing statement defined different elements for the two types of first-degree murder: premeditated murder, requiring killing, malice, and premeditation; and felony murder, requiring that a death be caused and that that death be caused in the commission of a felony. Id at 653-54.

126 FRCP 49; Hazard, Tait, and Fletcher, Pleading and Procedure at 1230 (cited in note 30) (noting that most states have a procedure for special verdicts or general verdicts with interrogatories). 
judges great discretion in determining the level of specificity appropriate in special verdicts or general verdicts with interrogatories, judges should use those tools to require juries to reach agreement on specifics.

\section{A. Problems with the Approaches in California and Kansas}

One threshold problem is that most courts have failed to address the important issue of how specifically jurors need to agree, although it must arise often. Those courts that have addressed the issue have proposed unsatisfactory solutions. First, there is no real agreement among the courts that have looked at the issue. Although the Kansas and California courts might often decide specificity cases in the same way, the approaches are so different that it is not hard to imagine cases in which they would reach different conclusions. Indeed, it is somewhat difficult to predict how the Kansas commonsense approach would come out in any difficult case.

Another problem with most of the current approaches is that they reject specificity requirements too quickly. The courts' and scholars' analyses fail to take into account the effects that allowing disagreement will have on deliberation and verdicts, effects that raise concerns about due process and fairness. ${ }^{127}$ If specificity is not required, jurors can render verdicts without fully fleshing out the differences among them.

The approach in California is particularly unsatisfactory for a number of reasons. First, the definitions of primary rights and cause of action can lead to rather arbitrary line-drawing. ${ }^{125}$ Moreover, the definition of the primary right in Stoner led to a potentially incorrect verdict. Several of the acts alleged by Stoner were discrete events, taking place at different times. ${ }^{129}$ If the jury did not agree on which of these discrete events Stoner had actually proven, it suggests there might be some flaws in her story. ${ }^{130}$ Nonetheless, the jury found in her favor. It seems plausible that the jurors were partly moved by compassion for a sympathetic plaintiff. The potential for decisions based on sympathy

127 See Part III.B.2.

128 The Supreme Court has disapproved of a somewhat similar approach in the criminal law context-the conceptual groupings approach advanced in Gipson, $553 \mathrm{~F} 2 \mathrm{~d}$ at 458 . See text accompanying notes 107-13 for a description of Gipson and the Supreme Court's rejection of it. See note 140 and accompanying text for a comparison of Stoner and Gipson.

129 For instance, Stoner alleged that the adoption agency misrepresented to her that her counseling would be fully confidential. Stoner, $54 \mathrm{Cal}$ Rptr $2 \mathrm{~d}$ at 247 . She also alleged that the agency misrepresented the legal effect of certain papers she was told to sign while in labor. See id.

130 Presumably for many of the events, Stoner was the primary or even sole witness for the plaintiff. Thus, if the jurors did not agree on which of the acts she alleged were proven, they all must have had some doubts about her credibility as a witness. 
for the plaintiff or even more pernicious grounds such as prejudice against a defendant is one of the strongest factors militating for a requirement of specificity.

\section{B. Lessons from the Criminal Law Context}

1. Distinguishing Schad: specificity is not required in the civil law context.

Most jurisdictions generally allow jurors to issue guilty verdicts without specific agreement on underlying facts. ${ }^{132}$ Therefore, the Stoner court reasoned that the civil law context should not impose a stricter requirement since the criminal law usually offers greater protections for the criminal defendant than the civil law does for the civil defendant. ${ }^{133}$

The Stoner court's reasoning was incorrect for a number of reasons. Judges deciding cases in the criminal context have been compelled to reach certain conclusions because of criminal statutes. For example, the Schad Court held that criminal defendants had no constitutional right to specific agreement and the statute was clear in denying a specificity requirement. ${ }^{134}$ Judges deciding civil matters are generally not constrained by statutes in this way; thus, they can make the best policy decision on specificity.

Schad relied on legislative intent to determine what level of specificity was required. ${ }^{135}$ It was not a decision about what level of specificity would be appropriate if the Supreme Court were free to make its own determination. Indeed, in Schad, the Court noted that more agreement might well be desired and that the legislature's formulation might not be the best, normatively speaking. ${ }^{136}$ Thus, although Schad and other criminal law decisions held that specificity was not required, this does not mean that specificity is not desirable in the civil law context.

The Schad analysis of legislative intent does not apply in the civil law context. Although state legislatures have passed some legislation regarding tort law, much tort law is based on common law prece-

131 See text accompanying notes 144-45. See also Hans and Vidmar, Judging the Jury at 131-48 (cited in note 3 ) (discussing how sympathy and prejudice sometimes influence jury verdicts).

132 See, for example, Stoner, 54 Cal Rptr 2d at 249-50 (collecting cases).

133 Id at 251-52.

134 Schad, 501 US at 645.

135 Id at 638 ("Respect for this legislative competence counsels against judicial secondguessing.").

136 Id at 645 ("We do not, of course, suggest that jury instructions requiring increased verdict specificity are not desirable."). 
dents. ${ }^{137}$ Indeed, legislatures do not have the same sort of interests in legislating in the civil law context that they have when legislating against criminal behavior. Cases like Schad recognize that state legislatures' decisions in defining crimes are entitled to deference because of the state's interest in convicting criminals. ${ }^{138}$ Although the state's interest in conviction may be balanced with some interest in the due process rights of criminal defendants, it is the courts that usually enforce such rights, not the state legislatures. ${ }^{139}$ In the civil context, the state generally does not have the same interest in favoring either plaintiffs or defendants, so an analysis deferring to the legislature does not make sense.

Thus, since the legislature's view of specificity in the civil law context is not especially well developed, and since the legislature does not have the same interests in the civil law as it does in convicting criminals, the best normative rule should be followed. Backing for specificity in the civil context comes from the Supreme Court's explicit rejection of Gipson's conceptual grouping test as "too indeterminate to provide concrete guidance to courts faced with verdict specificity questions. ${ }^{140}$ This same criticism can be leveled against the Stoner court's adoption of the primary rights theory. Similarly, Cleveland's intuitive approach gives even less guidance to courts struggling with the issue of specificity.

Schad also does not require specificity in the civil law context because such a requirement would not systematically disadvantage the plaintiff in the way that it would systematically disadvantage the criminal prosecutor. The Stoner court assumes that requiring specificity would work to the detriment of plaintiffs, ${ }^{141}$ and indeed, in Stoner itself, that is true. However, requiring specificity will sometimes work to help plaintiffs, such as when defendants allege multiple sets of facts as defenses. There is certainly an empirical question whether defendants or plaintiffs will receive more of the actual benefits of requiring specificity; however, it is not clear ex ante whether requiring specificity will help the defendant or the plaintiff in any particular case.

137 Dobbs, Law of Torts at 1 (cited in note 17) ("Tort law is predominantly common law.").

138 Schad, 501 US at 649 (Scalia concurring) ("[T] he general rule that when a single crime can be committed in various ways, jurors need not agree upon the mode of commission ... is not only constitutional, it is probably indispensable in a system that requires a unanimous jury verdict to convict."). See also id at 638 (majority) ("It goes without saying that preventing and dealing with crime is much more the business of the States ... and that we should not lightly construe the Constitution so as to intrude upon the administration of justice by the individual States.").

139 Indeed, because the state is actually the prosecutor in criminal cases, it have may have an interest in tilting the balance in its own favor when defining crimes.

140 Schad, 501 US at 635.

141 Stoner, 54 Cal Rptr 2d at 252-54. 
2. Due process and fairness concerns from the criminal law context.

Due process concerns also support specificity. Subsequent to Schad, the Supreme Court has recognized that fairness requires limits on the amount of disagreement that can be allowed in the criminal context. In Richardson $v$ United States, ${ }^{142}$ the Court required juror unanimity on the three particular violations that fell under the continuing criminal enterprise statute, since to do otherwise might aggravate the danger of verdicts based on something other than the facts.

Allowing disagreement in the civil context may also cover up inappropriate factors that may influence juries in civil verdicts to return verdicts in favor of plaintiffs despite disagreement on the facts. One much discussed factor that does sometimes seem to influence juries is the deep-pocket effect. ${ }^{14}$ The deep-pocket effect suggests that jurors award larger awards to plaintiffs suing wealthy defendants, particularly corporations. ${ }^{1.5}$ Allowing jury disagreement would presumably only enhance the deep-pocket effect.

\section{Additional Benefits of Specificity}

The civil jury remains more of a factfinding and less of a lawmaking body than the criminal jury. Special verdicts may not ordinarily be submitted to criminal juries. ${ }^{166}$ Thus, having jurors agree on specific facts is entirely in line with their factfinding strengths. Nor does agreement on specific facts mean that mixed law-fact questions like negligence are being taken away from jurors, since they may still answer such questions; they need only agree on the specifics behind the elements.

This solution may also help to improve the quality of the civil jury's deliberation. Several procedural innovations in the civil jury may already have affected the quality of jury deliberations in a negative way. The movement from unanimity to a form of majority verdict

142526 US 813 (1999).

143 Id at 819 (noting that if unanimity is not required, this may "cover up wide disagreement among the jurors about just what the defendant did, or did not, do" and "aggravate[ ] the risk (present at least to a small degree whenever multiple means are at issue) that jurors, unless required to focus upon specific factual detail, will fail to do so, simply concluding from testimony, say, of bad reputation, that where there is smoke there must be fire").

144 See MacCoun, Inside the Black Box at 162-63 (cited in note 52) (discussing the deeppocket effect and suggesting that it is better characterized as a "corporate identity effect" because juries seem more influenced by the presence of a corporate defendant than an individual with the wealth equivalent to a corporation).

145 Id.

146 United States v Spock, 416 F2d 165, 180 (1st Cir 1969) (noting that although special verdicts are an everyday occurrence in civil trials, they face a formidable array of objections in the criminal context). 
seems to change the quality of deliberation. ${ }^{147}$ Smaller juries may provide less diversity in deliberation. ${ }^{148}$ Requiring specificity will encourage better deliberation, since juries will not be able to render a verdict without reaching genuine agreement. Although this may cause slightly longer deliberations, better deliberations and verdicts are worth the cost. ${ }^{14}$

Deliberation on specifics should also improve the quality of verdicts whether jurors use quantitative methods or the story model in reaching their decisions. ${ }^{150}$ Both models of jury behavior focus on a juror's decision before deliberation. With the story model, requiring agreement will force jurors to reconsider the plausibility of their story and perhaps to include facts that they have left out. ${ }^{151}$ With meterreading models, requiring agreement should lead to discussion that will encourage jurors to reevaluate evidence that they may have discounted or ignored. ${ }^{152}$

\section{Implementation}

Few courts have considered the appropriate level of specificity, though surely it is an issue that often arises in jury trials. ${ }^{1.53}$ Litigants should address this issue when presenting evidence and requesting instructions. Judges should fashion instructions that consider this issue.

One significant exception to the general desirability of specificity is res ipsa loquitur cases. The nature of a res ipsa loquitur instruction makes it clear why specificity cannot be required in such cases. The Restatement (Second) of Torts explains:

147 Hans and Vidmar, Judging the Jury at 175 (cited in note 3) (noting that studies suggest that when unanimity is required, juries are more thorough in their evaluation of the evidence, minority jurors participate more actively in the discussion, and the jurors are more satisfied with the final verdict).

148 Id at 170 (explaining Justice Blackmun's conclusion in Ballew v Georgia, 435 US 223, 232-38 (1978), that empirical data has shown that smaller juries are less likely to engage in effective group deliberation, to represent different views in the community to counteract various biases, and to produce accurate verdicts).

149 See Wiggins and Breckler, $14 \mathrm{~L}$ \& Psych Rev at 6 (cited in note 45) (noting that special verdicts may be inefficient, but that this seems a small price to pay for higher-quality, more rational jury decisions).

150 See Part I.C.1.

151 The strength of a story depends partly on its coverage; a story that includes more facts revealed at trial will, other things being equal, be more convincing than a story including fewer facts. See Pennington and Hastie, The Story Model for Juror Decision Making at 198 (cited in note 46).

152 See David A. Schum and Anne W. Martin, Formal and Empirical Research on Cascaded Inference, in Reid Hastie, ed, Inside the Juror: The Psychology of Juror Decision Making 136, 169 (Cambridge 1993) (describing a study in which subjects who had already formed opinions about how to decide a case then treated testimony contradicting these formed opinions as either valueless or corroborative).

153 Since litigants may plead in the alternative, many plaintiffs no doubt argue multiple theories of liability and many defendants no doubt argue multiple defenses. 
It may be inferred that harm suffered by the plaintiff is caused by negligence of the defendant when: a) the event is of a kind which ordinarily does not occur in the absence of negligence; $b$ ) other responsible causes, including the conduct of plaintiff and third persons, are sufficiently eliminated by the evidence; and c) the indicated negligence is within the scope of the defendant's duty to the plaintiff. ${ }^{\text {is }}$

Thus, since the very essence of res ipsa loquitur is to recognize certain proof problems facing the plaintiff and to remove those problems by allowing an inference, ${ }^{i s 5}$ specificity could not possibly be required. With such a case, there are no specifics to agree upon.

The Restatement leaves discretion in the hands of the judge to determine whether the inference can reasonably be drawn or whether it must be drawn. ${ }^{1.56}$ If the court determines that different conclusions can be reasonably reached, the decision must be left in the hands of the jury. ${ }^{157}$ This Comment supports leaving this decision in the hands of the judge. If the judge thinks a res ipsa loquitur instruction is appropriate, he should give it; if not, he should instruct the jurors that they must agree specifically.

The choice of verdict form is potentially very important in cases where specificity of agreement is an issue. In such cases, it may be appropriate for a judge to use his discretion to require special verdicts or general verdicts with interrogatories in order to question the jury. In that way, the judge can ensure that jurors are agreeing with the required degree of specificity.

\section{CONCLUSION}

This Comment has evaluated the current approaches to specificity of agreement in the civil law context. It proposes that jurors should ordinarily have to agree on the facts of the case with greater specificity. Due process and fairness concerns, as well as the purpose and strengths of the civil law jury, support specificity. Moreover, because special verdicts and other tools give judges great discretion in crafting instructions, judges can easily implement a policy of asking jurors to agree on underlying facts.

154 Restatement (Second) of Torts § 328D (ALI 1965).

155 Richard A. Epstein, Cases and Materials on Torts 294 (Aspen 6th ed 1995) (noting that the function of res ipsa loquitur is to aid the plaintiff in proving the elements of a negligence case by circumstantial evidence).

156 Restatement (Second) of Torts $\$ 328 D$.

157 Id. 


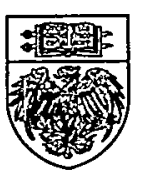

